\title{
Functionalization of mesoporous SBA-15 silica by grafting of polyvinylamine on epoxy-modified surface*)
}

\author{
Anna Wach ${ }^{1)}$, Piotr Natkański ${ }^{1}$, Marek Drozdek ${ }^{1)}$, Barbara Dudek ${ }^{1}$, Piotr Kuśtrowski ${ }^{1), * *)}$ \\ DOI: dx.doi.org/10.14314/polimery.2017.516
}

\begin{abstract}
Mesoporous SBA-15 silica was modified by grafting of 3-glycidoxypropyltrimethoxysilane (GPTMS). An influence of GPTMS/SBA-15 mass ratio used during this pre-functionalization step on the real amount of epoxy-silane grafted on the SBA-15 surface was studied by thermogravimetry and elemental analysis. The pre-functionalized SBA-15 was subsequently used to attach polyvinylamine (PVAm) chains by the opening of oxirane rings and the formation of bonds with $\mathrm{NH}_{2}$ groups from PVAm. The yield of this process was determined. Furthermore, SEM (scanning electron microscopy), DRIFT (diffuse reflectance infrared Fourier transform spectroscopy) and XPS (X-ray photoelectron spectroscopy) as well as zeta potential measurements were applied to observe the changes in the chemical composition of SBA-15 surface and morphology of the synthesized materials. Various types of organic functionalities present on the modified SBA-15 were identified and analyzed quantitatively.
\end{abstract}

Keywords: mesoporous silica, organic-inorganic hybrid materials, polymer grafting, polyvinylamine.

\section{Funkcjonalizacja mezoporowatej krzemionki SBA-15 w wyniku szczepienia poliwinyloaminy na powierzchni modyfikowanej grupami epoksydowymi}

Streszczenie: Powierzchnię mezoporowatej krzemionki SBA-15 zmodyfikowano na drodze szczepienia 3-glicydoksypropylotrimetoksysilanu (GPTMS). Z wykorzystaniem metod analiz elementarnej oraz termograwimetrycznej badano wpływ stosunku masowego GPTMS/SBA-15 zastosowanego we wstępnej modyfikacji na rzeczywistą zawartość wprowadzonych na powierzchnię krzemionki grup epoksydowych. Do powierzchni zmodyfikowanego SBA-15 przyłączono następnie łańcuchy poliwinyloaminy (PVAm) w wyniku reakcji otwierania pierścieni oksiranowych połączonej z utworzeniem wiązań z grupami $\mathrm{NH}_{2}$ pochodzącymi od PVAm. Określono wydajność tego procesu. Badania SEM (skaningowej mikroskopii elektronowej), DRIFT (spektroskopii odbicia rozproszonego w podczerwieni), XPS (spektroskopii fotoelektronów) oraz pomiary potencjału zeta pozwoliły na ocenę zmian składu chemicznego powierzchni SBA-15 oraz morfologii zsyntetyzowanych materiałów. Zidentyfikowano oraz oznaczono ilościowo różne rodzaje grup funkcyjnych obecnych na powierzchni modyfikowanej krzemionki SBA-15.

Słowa kluczowe: mezoporowata krzemionka, organiczno-nieorganiczne materiały hybrydowe, szczepienie polimeru, poliwinyloamina.

Since the development of new family of silicate/aluminosilicate mesoporous molecular sieves designated as M41S materials at the beginning of the 90's [1], a significant progress has been achieved in the area of ordered mesoporous silicas (OMS) that extend the range of pore sizes beyond those achievable in zeolites [2,3]. OMS with a regularly ordered pore arrangement, narrow pore size distribution, large pore volume as well as high surface area are highly suitable for modification with organic

\footnotetext{
1) Department of Chemical Technology, Faculty of Chemistry, Jagiellonian University, Ingardena 3, 30-060 Kraków, Poland.

*) This material was presented at $9^{\text {th }}$ International Conference MoDeSt 2016, 4-8 September 2016, Cracow, Poland.

**) Author for correspondence; e-mail: piotr.kustrowski@uj.edu.pl
}

species, tailoring their surface properties for numerous potential application including catalysis, adsorption, drug delivery, sensors, etc. [4-7]. The incorporation of various organic functional groups, either by in situ co-condensation or by postsynthetic grafting [8,9], permits to form active surface sites and improve desired properties (e.g., hydrophobicity/hydrophilicity, acidity/basicity) of OMS. Among various organic-silica hybrid materials, amino-modified mesoporous silicas were found to be highly effective catalysts in many base-catalyzed reactions, including aldol condensation, Michael addition, and Knoevenagel condensation [10-12].

In our previous publication [13], we presented a comparison of the polyvinylamine-silica hybrid materials synthesized by two different techniques, namely "grafting from" and "grafting onto" method. The influence of 


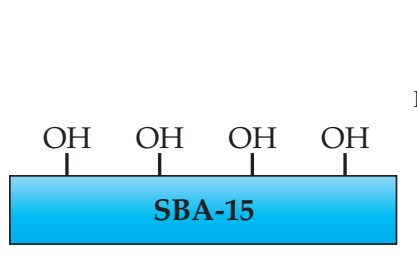

Surface silanol groups
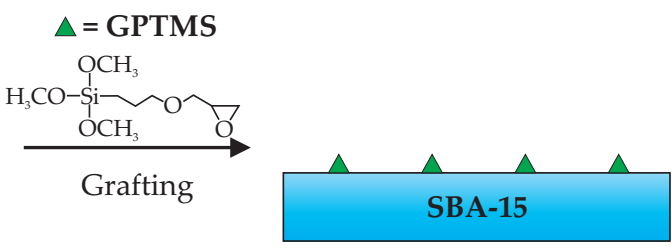

Surface functional groups

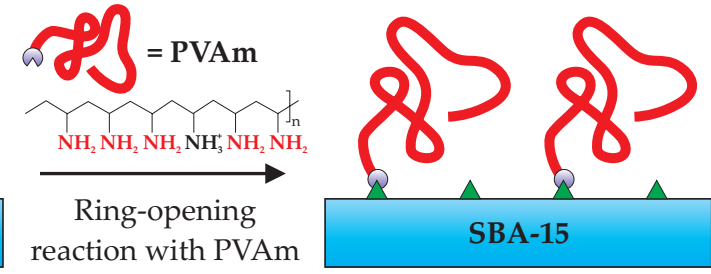

Hybrid material

Fig. 1. Synthesis of polyvinylamine/SBA-15 silica hybrid materials using the "grafting onto" method

the modification method on the catalytic activity in the Knoevenagel condensation between benzaldehyde and ethyl cyanoacetate was evidenced. The main objective of the present study is to discuss in details the functionalization of ordered hexagonal mesoporous SBA-15 silica with polyvinylamine (PVAm) by the "grafting onto" method. The studied hybrid materials are synthesized by a two-step procedure, as schematically shown in Fig. 1. Firstly, the silica particles are grafted with 3-glycidoxypropyltrimethoxysilane (GPTMS), which provides highly reactive epoxy functionalities on the SBA-15 surface. The modification of the silica support with this coupling agent favors irreversible anchoring of polymer chains, which are initially incompatible with the silica surface. In the second step, the PVAm chains are attached to the surface of epoxy-functionalized silica over the course of ring-opening reaction. This work highlights changes in the distribution of organic species deposited on the SBA-15 surface during all modifications steps as well as the mechanism of interaction between polymer and silica surface.

\section{EXPERIMENTAL PART}

\section{Materials and synthesis}

In the first step, the mesoporous SBA-15 silica, prepared using the same procedure as previously described [14], was functionalized with various amounts of 3-glycidoxypropyltrimethoxysilane (GPTMS, $98 \%$, Aldrich). Briefly, $2.0 \mathrm{~g}$ of SBA-15 (dried at $200{ }^{\circ} \mathrm{C}$ overnight) was dispersed in $50 \mathrm{~cm}^{3}$ of anhydrous toluene. Afterwards, the calculated amount of GPTMS was added to obtain the intended GPTMS/SBA-15 mass ratio of 0.10, 0.25, 0.50, 0.75, 1.00, 1.50 or 2.00. The suspension was refluxed for $6 \mathrm{~h}$ under an inert atmosphere. The epoxy-functionalized product was recovered by filtration, washed with anhydrous toluene and methanol and dried under vacuum at $50{ }^{\circ} \mathrm{C}$. The resulting materials are referred to as SBA-15_GPTMS_x, where $\mathrm{x}$ is the intended GPTMS/SiO${ }_{2}$ mass ratio.

PVAm was synthesized independently by the radical polymerization of $\mathrm{N}$-vinylformamide (NVF) followed by base-catalyzed hydrolysis. For this purpose, $25 \mathrm{~g}$ of freshly distilled $\mathrm{N}$-vinylformamide $(98.0 \%$, Aldrich) and $475 \mathrm{~g}$ of distilled water were stirred and degassed at room temperature. The mixture was then heated to $65^{\circ} \mathrm{C}$, and 2,2'-azobis(2-methylpropionamidine) dihydrochloride (AAPH, 97.0 \%, Aldrich) was added at the AAPH/NVF molar ratio of 0.01 . The polymerization was performed for $4 \mathrm{~h}$ under an inert atmosphere. Subsequently, $500 \mathrm{~cm}^{3}$ of $4 \mathrm{~mol} / \mathrm{dm}^{3} \mathrm{NaOH}$ was added to the mixture with formed poly( $N$-vinylformamide) (PNVF) and hydrolyzed for $4 \mathrm{~h}$ to ensure the complete conversion of amide groups into amino ones. After purification by dialysis, PVAm was dried under vacuum at $50{ }^{\circ} \mathrm{C}$.

In the second step, the pre-prepared polyvinylamine chains were attached to the surface of epoxy-functionalized silica (SBA-15_GPTMS_2.00) over the course of ring-opening reaction. In a typical procedure, $2.15 \mathrm{~g}$ of the epoxy-functionalized SBA-15 was dispersed in $250 \mathrm{~cm}^{3}$ of distilled water. Subsequently, the amount of PVAm, corresponding to the intended $\mathrm{PVAm} / \mathrm{SiO}_{2}$ mass ratio of 0.10 , $0.25,0.50,0.75,1.00,1.50,2.00$ or 2.50 , was added. The reaction was carried out at $60^{\circ} \mathrm{C}$ for $6 \mathrm{~h}$ under an inert atmosphere. Finally, the resulting solid was filtered, washed with distilled water and dried under vacuum at $50{ }^{\circ} \mathrm{C}$. The prepared hybrid materials with the different PVAm loadings are denoted as SBA-15_GPTMS_PVAm_x, where $x$ means the intended $\mathrm{PVAm} / \mathrm{SiO}_{2}$ mass ratio.

\section{Methods of testing}

Carbon, hydrogen and nitrogen contents were determined in a EURO EA 3000 elemental analyzer (EuroVector). Thermogravimetric analyses (TG) were performed on a SDT Q600 thermobalance (TA Instruments). Samples were placed in a corundum crucible and heated in flowing air $\left(100 \mathrm{~cm}^{3} / \mathrm{min}\right)$ from 30 to $1000{ }^{\circ} \mathrm{C}$ at the rate of $20^{\circ} \mathrm{C} / \mathrm{min}$.

Diffuse reflectance infrared Fourier transform (DRIFT) spectra were recorded with a Thermo Scientific Nicolet 6700 Fourier transform infrared (FT-IR) spectrometer equipped with a DRIFT device and a narrow band MCT-A detector. The FT-IR spectrum of $\mathrm{KBr}$ was used as a background. Prior to the DRIFT measurements, samples were diluted to $4 \mathrm{wt} \%$ in $\mathrm{KBr}$, softly milled in an agate mortar and placed in a sample holder. Typically, 200 scans were acquired for each spectrum in the range of $650-4000 \mathrm{~cm}^{-1}$ with the resolution of $4 \mathrm{~cm}^{-1}$.

X-ray photoelectron spectroscopy (XPS) measurements were performed on a Prevac photoelectron spectrometer equipped with a hemispherical VG SCIENTA R3000 
analyzer. The spectra were taken using a monochromatized aluminium source $\operatorname{AlK}_{\alpha}(E=1486.6 \mathrm{eV})$ and a low-energy electron flood gun (FS40A-PS) to compensate for the charge accumulation on the surface of nonconductive samples. The pressure in the analysis chamber was maintained at $5 \cdot 10^{-7} \mathrm{~Pa}$. For each sample, the Si $2 \mathrm{p}, \mathrm{O} 1 \mathrm{~s}, \mathrm{C} 1 \mathrm{~s}$, $\mathrm{N} 1 \mathrm{~s}$ and $\mathrm{Cl} 2 \mathrm{p}$ spectra were recorded with a $100 \mathrm{eV}$ pass energy. The core level spectra were fitted using Casa XPS software version 2.3.16 with symmetric mixed Gaussian-Lorentzian line-shapes at a fixed ratio of $70 \%$ Gaussian and $30 \%$ Lorentzian. The binding energies were calibrated to $\mathrm{Si} 2 \mathrm{p}$ in $\mathrm{SiO}_{2}\left(E_{b}=103.6 \mathrm{eV}\right)$.

The porous structure of the mesoporous support as well as hybrid materials was characterized by $\mathrm{N}_{2}$ physisorption at $-196{ }^{\circ} \mathrm{C}$ using an ASAP 2020 Micromeritics instrument. Prior to each measurement, a sample was degassed at $120{ }^{\circ} \mathrm{C}$ for $10 \mathrm{~h}$ under vacuum. The pore size distribution was determined from the adsorption branches of isotherm using the Barrett-Joyner-Halenda (BJH) method and the specific surface area was calculated according to the Brunauer-Emmett-Teller (BET) model. The total pore volume was calculated on the basis of the nitrogen amount adsorbed at the relative pressure $\left(p / p_{0}\right)$ of 0.99 .

Scanning electron microscopy (SEM) images were collected on a Hitachi S-4700 microscope, equipped with a Noran Vantage analyzer, under low-vacuum conditions and accelerating voltage of $15 \mathrm{kV}$. Samples were prepared by placing powder on a double-sided carbon adhesive tape mounted on a sample holder and then sputtered with a thin carbon film to minimize the charging effects.

The surface zeta potential $(Z P)$ and volumetric particle size distribution (PSD) of SBA-15 before and after modification were determined using a Zeta Acoustic Particle Sizer (Zeta-APS, Matec Applied Sciences). PSD was measured by means of AAS (acoustic attenuation spectroscopy) method. Typically, $0.2 \mathrm{~g}$ of a sample was dispersed in $200 \mathrm{~cm}^{3}$ of distilled water and the suspension was sonicated in an ultrasonic bath for $10 \mathrm{~min}$. The measurements were carried out at the constant temperature $\left(25^{\circ} \mathrm{C}\right)$ for colloidal samples in the particle size range of $10 \mathrm{~nm}-100 \mu \mathrm{m}$.

\section{RESULTS AND DISCUSSION}

\section{Pre-functionalization of SBA-15 with GPTMS}

The "grafting onto" method, selected to introduce amine moieties on the SBA-15 surface, demanded the initial functionalization of the silica support with GPTMS at carefully controlled conditions. This first step was necessary, as the epoxy groups attached to the silica surface enable to form covalent bonds between SBA-15 and PVAm chains. To choose the proper amount of GPTMS for the covering of whole SBA-15 surface, the pre-functionalization step was studied at various GPTMS/SBA-15 mass ratios. The obtained materials were examined by elemental analysis CHN, TG and XPS.
The TG measurements were applied to analyze the actual loading of epoxy groups on the SBA-15 surface (TG and DTG curves for the silica support and the selected SBA-15_GPTMS_x samples are shown in Fig. 2). The bare silica reveals a mass loss of approximately $3.3 \%$, which is associated with the evaporation of physically adsorbed water $\left(<150{ }^{\circ} \mathrm{C}\right)$ and dehydroxylation of surface silanols $\left(150-1000{ }^{\circ} \mathrm{C}\right)$ [15].

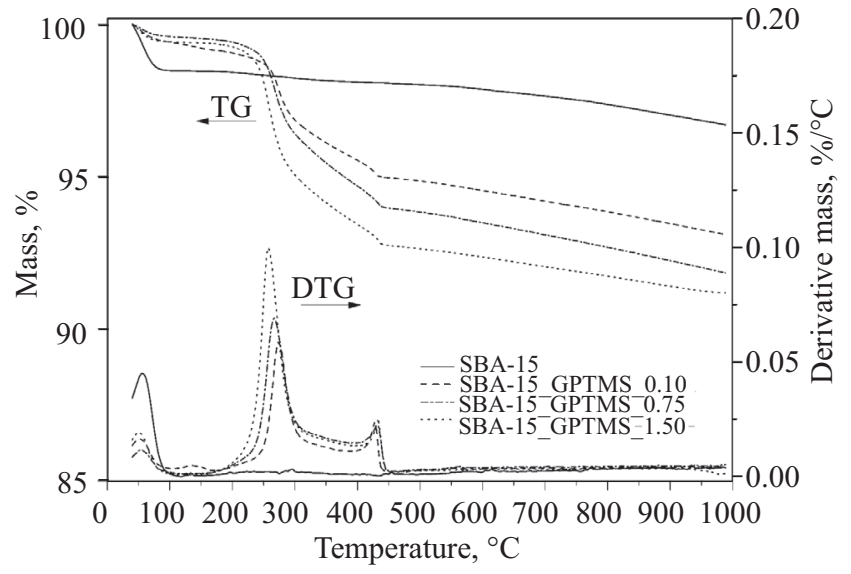

Fig. 2. TG and DTG curves collected for pristine SBA-15 and selected epoxy-functionalized silica samples under oxidizing atmosphere

After the functionalization of SBA-15 with GPTMS, the total mass loss notably increases, proving the successful attachment of epoxy groups to the $\mathrm{SiO}_{2}$ surface. Regardless of the intended organic content, the mass loss profiles are similar in shape. Two distinct DTG maxima, characteristic of decomposition of GPTMS molecules, are observed at about 270 and $440{ }^{\circ} \mathrm{C}[16,17]$. In order to estimate correctly the amount of organic species grafted to the SBA-15 surface, the elimination of silanols from the pure silica support was taken into account for the mass loss in the temperature between 150 and $450{ }^{\circ} \mathrm{C}$. The results are reported in Table 1.

As can be seen, the amount of epoxy-silane on the surface of SBA-15 increases progressively with rising the intended GPTMS loading reaching similar values for the samples with the intended GPTMS/SiO${ }_{2}$ mass ratios above 1.00. The observed changes in the epoxy-silane loading are also confirmed by elemental analysis (Table 1).

In order to study the type of functional groups and their surface composition, the epoxy-functionalized SBA-15 materials were characterized by XPS. The typical high-resolution $C$ 1s spectra are displayed in Fig. 3, while the atomic concentration and core-level binding energy values for surface species are summarized in Table 1.

In accordance with the literature [18, 19], the precise deconvolution of $C 1$ s core level spectra reveals the presence of three components related to various types of carbon atoms in the GPTMS molecule. The peak at binding energy of $284.7 \pm 0.1 \mathrm{eV}$ is attributed to the C-C and C-H bonds in alkyl groups and hydrocarbon contamination. The most intensive peak at $286.4 \pm 0.1 \mathrm{eV}$ points out the presence of 
T a b l e 1. Chemical composition of SBA-15 modified with different amounts of GPTMS

\begin{tabular}{|c|c|c|c|c|c|c|c|c|c|}
\hline \multirow{3}{*}{ Sample } & \multirow{3}{*}{$\begin{array}{c}\text { TG } \\
\text { analysis } \\
\begin{array}{c}\text { Organic } \\
\text { wt \% }\end{array}\end{array}$} & \multirow{2}{*}{\multicolumn{2}{|c|}{ Elemental analysis }} & \multicolumn{6}{|c|}{ Surface composition (at \%) } \\
\hline & & & & \multicolumn{3}{|c|}{$\mathrm{C} 1 \mathrm{~s}$} & \multicolumn{2}{|c|}{ O 1s } & \multirow{2}{*}{$\begin{array}{c}\text { Si } 2 p \\
\underline{\mathrm{SiO}}_{2} \\
(103.6 \mathrm{eV})\end{array}$} \\
\hline & & $\begin{array}{c}\mathrm{C} \\
\text { wt \% }\end{array}$ & $\begin{array}{c}\mathrm{H} \\
\mathrm{wt} \%\end{array}$ & $\begin{array}{c}\underline{C}-\mathrm{C}, \underline{\mathrm{C}-\mathrm{H}} \\
(284.7 \\
\pm 0.1 \mathrm{eV})\end{array}$ & $\begin{array}{c}\mathrm{C}-\mathrm{O} \\
(286.4 \\
\pm 0.1 \mathrm{eV})\end{array}$ & $\begin{array}{c}\mathrm{C}-\mathrm{O}-\mathrm{C} \\
(287.3 \\
\pm 0.1 \mathrm{eV})\end{array}$ & $\begin{array}{c}\text { Si-O }-\mathrm{C} \\
(532.3 \\
\pm 0.1 \mathrm{eV})\end{array}$ & $\begin{array}{c}\mathrm{SiO}_{2}, \mathrm{C}-\underline{\mathrm{O}}-\mathrm{C} \\
(532.9 \\
\pm 0.1 \mathrm{eV})\end{array}$ & \\
\hline SBA-15 & - & 0.06 & 0.64 & - & - & - & - & 65.20 & 34.80 \\
\hline SBA-15_GPTMS_0.10 & 3.86 & 2.33 & 0.95 & 1.07 & 1.44 & 0.90 & 0.54 & 63.10 & 32.95 \\
\hline SBA-15_GPTMS_0.25 & 4.05 & 2.44 & 0.92 & 1.17 & 1.56 & 0.99 & 0.57 & 62.61 & 33.10 \\
\hline SBA-15_GPTMS_0.50 & 4.93 & 2.83 & 0.97 & 1.32 & 1.74 & 1.14 & 0.60 & 62.22 & 32.98 \\
\hline SBA-15_GPTMS_0.75 & 5.18 & 3.39 & 1.03 & 1.64 & 2.07 & 1.35 & 0.72 & 61.84 & 32.39 \\
\hline SBA-15_GPTMS_1.00 & 6.62 & 4.11 & 1.13 & 1.91 & 2.69 & 1.82 & 0.87 & 60.81 & 31.91 \\
\hline SBA-15_GPTMS_1.50 & 6.26 & 3.55 & 1.05 & 1.93 & 2.76 & 1.84 & 0.92 & 60.45 & 32.10 \\
\hline SBA-15_GPTMS_2.00 & 7.07 & 3.83 & 1.31 & 1.98 & 2.78 & 1.85 & 0.93 & 60.47 & 31.99 \\
\hline
\end{tabular}

C-O moieties in ether linkages and most probably some unreacted methoxy groups. The higher binding energy feature at $287.3 \pm 0.1 \mathrm{eV}$ originates mainly from the carbon atoms in the oxirane rings. In the high-resolution $\mathrm{O} 1 \mathrm{~s}$ spectra (not shown here) obtained after the silanization, we observe peaks representing two different $\mathrm{O}$ species. The predominant peak at binding energy of $532.9 \pm 0.1 \mathrm{eV}$ corresponds to lattice oxygen in silicon dioxide as well as oxygen bonded to carbon (the C-O-C bonds). The second component at lower binding energies $(532.3 \pm 0.1 \mathrm{eV})$ reflects the presence of oxygen in a $\mathrm{Si}-\mathrm{O}-\mathrm{C}$ units, resulting from unhydrolyzed methoxy groups (the $\mathrm{Si}-\mathrm{O}-\mathrm{C}$ bonds) [20]. The XPS results clearly indicate that the majority of methoxy groups in GPTMS molecules underwent hydrolysis during the grafting procedure. On the other hand, anhydrous conditions allowed to reduce the self-conden-

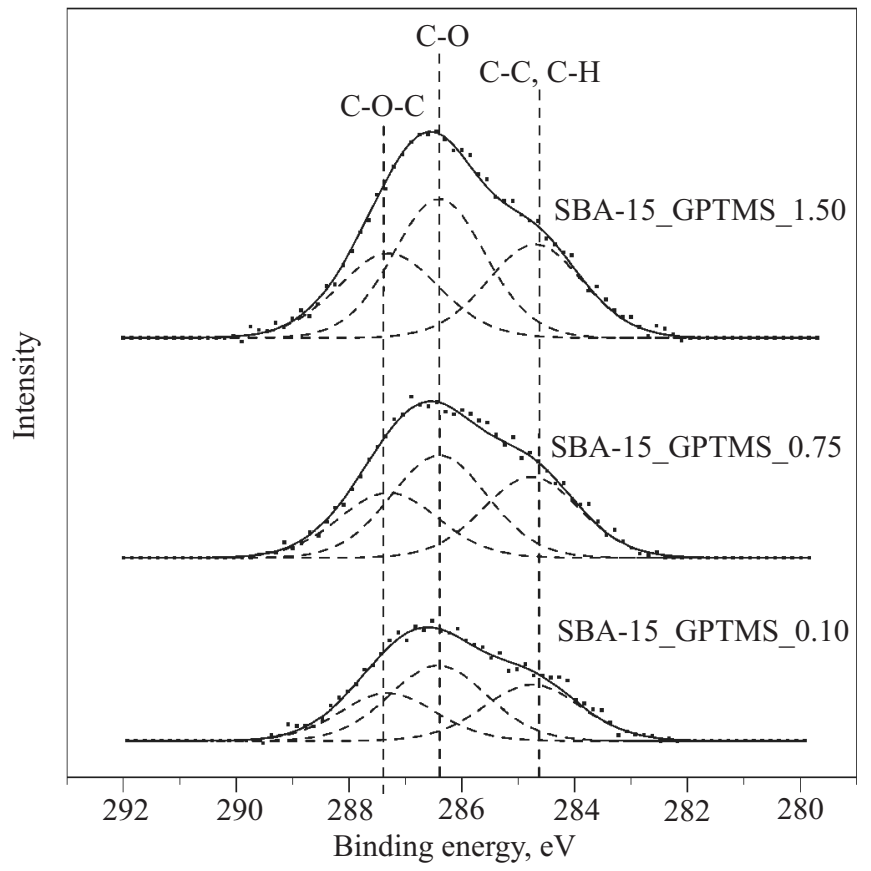

Fig. 3. Representative high-resolution C 1s spectra of SBA-15 silica grafted with different amounts of GPTMS sation of GPTMS molecules, which could lead to the formation of island structures of aggregated epoxy-silane [21].

\section{Deposition of PVAm on epoxy-functionalized SBA-15}

The amino-based polymers can be irreversibly attached to the surface of epoxy-functionalized silica through ring-opening, which is a well-known reaction in the organic chemistry [22]. In this work, we selected polyvinylamine as a polymer with the highest density of reactive primary amino groups along the backbone, to demonstrate the feasibility of polymer grafting. In order to ensure the highest possible content of chemically bonded polymer in the hybrid material, the epoxy-modified SBA-15 with the highest concentration of anchored GPTMS (SBA-15_GPTMS_2.00) was used. The grafting efficiency was monitored by TG analysis (TG and DTG curves for the SBA-15 support and the selected SBA-15_GPTMS_PVAm samples are shown in Fig. 4).

Thermal decomposition of PVAm in the silica-based hybrid materials proceeds via two well-resolved steps. The first characteristic mass loss with a sharp DTG maximum at $230{ }^{\circ} \mathrm{C}$ is assigned to the elimination of amino

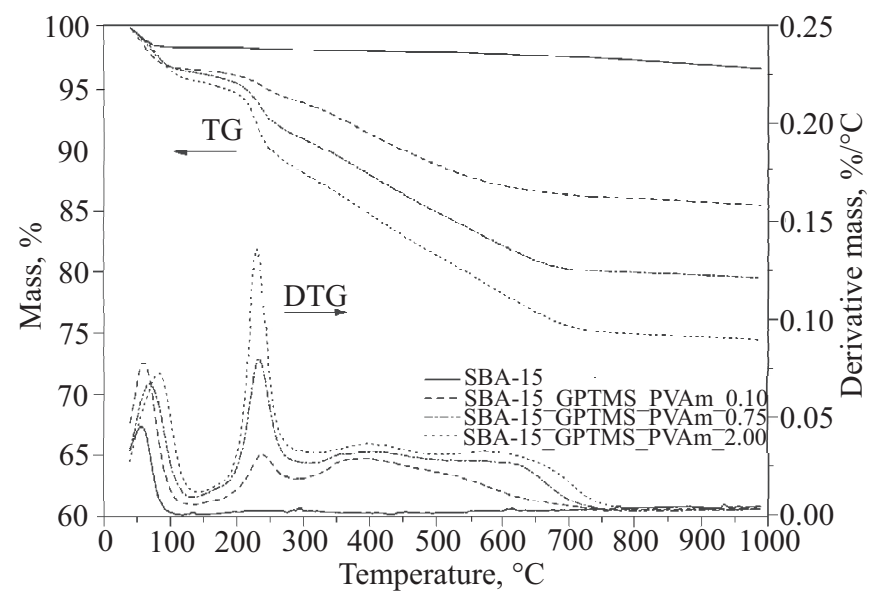

Fig. 4. TG and DTG curves measured for representative polyvinylamine/SBA-15 hybrid materials 
T a b 1 e 2. Physicochemical properties of SBA-15 silica modified with different amounts of polyvinylamine

\begin{tabular}{|c|c|c|c|c|c|c|c|c|c|}
\hline \multirow[b]{2}{*}{ Sample } & \multicolumn{3}{|c|}{ Textural parameters } & \multirow{2}{*}{$\begin{array}{c}\text { TG analysis } \\
\text { Polymer } \\
\text { content } \\
\text { wt \% }\end{array}$} & \multicolumn{2}{|c|}{ Elemental analysis } & \multicolumn{3}{|c|}{ Zeta potential analysis } \\
\hline & $\begin{array}{c}S_{\text {BET }} \\
\mathrm{m}^{2} / \mathrm{g}\end{array}$ & $\begin{array}{c}V_{\text {total }} \\
\mathrm{cm}^{3} / \mathrm{g}\end{array}$ & $\begin{array}{c}D_{\mathrm{BJH}} \\
\mathrm{nm}\end{array}$ & & $\begin{array}{c}\mathrm{C} \\
\text { wt } \%\end{array}$ & $\begin{array}{c}\mathrm{N} \\
\mathrm{wt} \%\end{array}$ & $\begin{array}{l}\mathrm{ZP} \\
\mathrm{mV}\end{array}$ & $\begin{array}{c}\text { Average size } \\
\text { of particle } \\
\mathrm{nm}\end{array}$ & $\begin{array}{c}\text { Range of } \\
\text { particle size } \\
\mathrm{nm}\end{array}$ \\
\hline SBA-15 & 925 & 1.05 & 7.3 & - & 0.06 & - & -37.00 & 98 & $11-165$ \\
\hline SBA-15_GPTMS_2.00 & 718 & 0.84 & 7.0 & - & 3.83 & - & -25.79 & $76 ; 130$ & $10-160$ \\
\hline SBA-15_GPTMS_PVAm_0.10 & 576 & 0.83 & 7.3 & 2.89 & 5.35 & 0.94 & 27.73 & $76 ; 122$ & $10-160$ \\
\hline SBA-15_GPTMS_PVAm_0.25 & 515 & 0.78 & 7.4 & 5.74 & 6.17 & 1.89 & 29.65 & 50 & $10-82$ \\
\hline SBA-15_GPTMS_PVAm_0.50 & 472 & 0.74 & 7.5 & 7.67 & 7.16 & 2.44 & 41.66 & 34.5 & $9-55$ \\
\hline SBA-15_GPTMS_PVAm_0.75 & 408 & 0.67 & 7.5 & 9.20 & 8.00 & 2.94 & 40.03 & 35 & $8-54$ \\
\hline SBA-15_GPTMS_PVAm_1.00 & 389 & 0.64 & 7.4 & 10.17 & 8.55 & 3.32 & 40.04 & 35 & $9-50$ \\
\hline SBA-15_GPTMS_PVAm_1.50 & 377 & 0.63 & 7.4 & 12.63 & 9.88 & 4.01 & 42.66 & 32 & $8-54$ \\
\hline SBA-15_GPTMS_PVAm_2.00 & 361 & 0.60 & 6.9 & 14.01 & 10.92 & 4.58 & 42.35 & 33.5 & $9-54$ \\
\hline SBA-15_GPTMS_PVAm_2.50 & 340 & 0.56 & 6.6 & 16.10 & 11.60 & 5.00 & 40.71 & 34 & $8-52$ \\
\hline
\end{tabular}

moieties [23]. Moreover, a continuous mass loss in the temperature range of $300-750{ }^{\circ} \mathrm{C}$, accompanied by a very broad exothermic effect is observed. This process is related to the combustion of polymer chains located in the SBA-15 channels. It is most likely that the pore geometry restricts diffusion of evolved gaseous products and shifts the range of effective burning toward higher temperatures. The content of the polymer in the hybrid materials, evaluated by the mass loss in the range of $150-1000{ }^{\circ} \mathrm{C}$, excluding the contribution of GPTMS and silanol decomposition, is shown in Table 2.

The estimated loadings of PVAm in the hybrid materials increase from 2.89 (for SBA-15_GPTMS_PVAm_0.10) to $16.10 \mathrm{wt} \%$ (for SBA-15_GPTMS_PVAm_2.50). On the other hand, it was recognized that for the ideally pure PVAm sample, the mass ratio of carbon to nitrogen is ca. 1.86 [24]. In comparison, the values of $\mathrm{C} / \mathrm{N}$ ratios for the studied PVAm/SBA-15 materials (cf. Table 2) are appreciably higher than the expected one (from 5.72 for SBA-15_GPTMS_ PVAm_0.10 to 2.32 for SBA-15_GPTMS_PVAm_2.50). This finding can be explained by the relatively high content of carbon originating from the epoxy-silane coupling agent. Therefore, only nitrogen can be considered as a unique elemental marker useful in the determination of the PVAm content. Analyzing the amount of nitrogen, the progressive increase in the PVAm loading is found, that is fully compatible with the TG results.

Nitrogen sorption measurements reveal differences in the pore structure of the synthesized hybrid materials. All studied materials exhibit type IV isotherms (not shown here) with distinct hysteresis loops, which are characteristic of capillary condensation of nitrogen inside large cylindrical mesopores [25]. The textural parameters of the synthesized materials involving total pore volume, BET surface area and average pore size are presented in Table 2. After the PVAm grafting, the quantity of nitrogen adsorbed (i.e., total pore volume) as well as the surface area of SBA-15 gradually decreases as the functionalization progressed. The synthesized silica support exhibits a very narrow pore size distribution centered at about $7.3 \mathrm{~nm}$. It is noteworthy that in the case of the hybrid materials with a low content of polymer species (the samples with the intended PVAm $/ \mathrm{SiO}_{2}$ mass ratio from 0.10 to 0.75 ), an increase in the average pore diameter is observed. This effect can be attributed to densification of silica walls during the stepwise modification of silica, which has already been reported in the literature [26, 27]. However, a further increase in the polymer content results in a decrease of mean pore diameter from $7.5 \mathrm{~nm}$ (for SBA-15_GPTMS_ PVAm_0.75) to $6.6 \mathrm{~nm}$ (for SBA-15_GPTMS_PVAm_2.50). These results suggest a gradual filling of silica mesopores, which may cause pore-blocking effects [28]. Moreover, some polymer species are probably deposited on the outer surface of the silica support. Nevertheless, it should be stressed that the overall mesoporous structure of SBA-15 silica is not changed during the PVAm grafting process.

Zeta potential measurements are often used as an important tool to evaluate the surface charge of organic-modified silica materials [29, 30]. This is mainly due to the fact that the surface charge is very sensitive to the chemical nature of functional groups present on the surface of inorganic support. The values of zeta potential determined for the pristine and PVAm-modified SBA-15 are presented in Table 2. In agreement with literature data $[30,31]$, the zeta potential of the unmodified silica support equals to $-37.00 \mathrm{mV}$ (at $\mathrm{pH}=5.5$ ). It is widely known that above the isoelectric point (at $\mathrm{pH}=2.7-3.7$ for SBA-15) the surface of silica is negatively charged due to the presence of silanolate ions ( $\left.\mathrm{Si}-\mathrm{O}^{-}\right)$. The functionalization of the silica surface with GPTMS leads to a slight increase in the value of zeta potential. Such behavior indicates partial participation of silanol groups in chemical bonding with epoxy-silane molecules. Furthermore, the attachment of PVAm chains results in substantial changes of surface charge toward positive values. As presented, the values of zeta potential increase progressively with rising the polymer content up to the intended $\mathrm{PVAm} / \mathrm{SiO}_{2}$ mass ratio equal to 0.50 . These results can be explained by cov- 


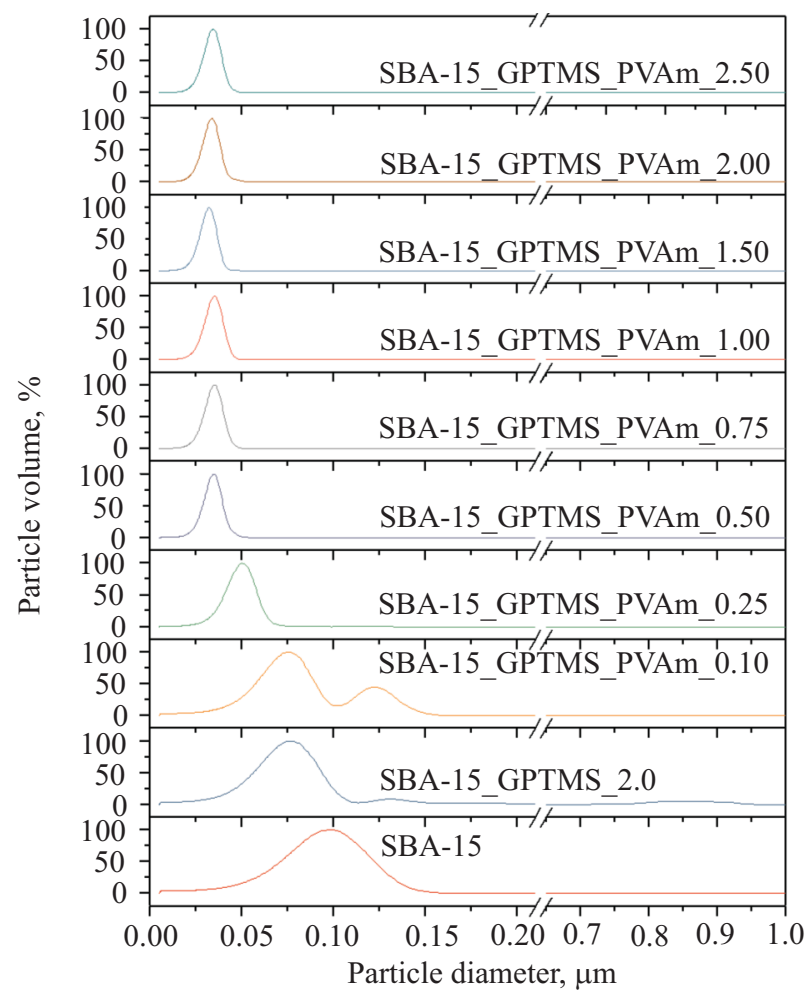

Fig. 5. Volumetric particle size distributions for SBA-15, SBA-15_GPTMS_2.00 and series of SBA-15_GPTMS_PVAm_x $(x=0.10-2.50)$ materials

ering of the most silanol groups by introduced polymer chains as well as by introduction of primary amino groups. With the further increase in the PVAm content, zeta potential is maintained at the constant level of $c a$. $40.0-42.7 \mathrm{mV}$, which confirms a complete surface functionalization of SBA-15.

Simultaneously, the particles size distributions were also determined. The volumetric diameter distributions for SBA-15 before and after modification, as well as the average particle diameters are presented in Fig. 5 and Table 2, respectively. The introduction of organic modifier and polymer on the silica surface strongly influences PSD. The widest range of particle diameters (from 11 to $165 \mathrm{~nm}$ ) is found for unmodified SBA-15 silica character-

a)

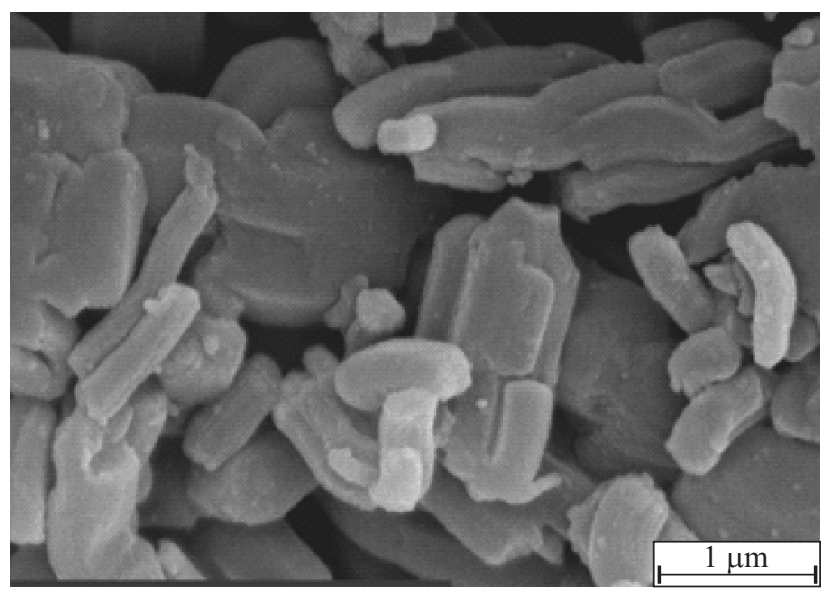

ized by the average particles diameter equals to $98 \mathrm{~nm}$. After the functionalization of the silica support with GPTMS, as well as the attachment of the smallest amount of polymer (for SBA-15_GPTMS_PVAm_0.10) a bimodal distribution of grain size is observed in the similar range as for SBA-15_GPTMS. A further increase in the PVAm content leads to a decrease in the average particles size as well as an increase of homogeneity. It is clearly seen that the PSD curves are strongly correlated to the zeta potential values. The narrowing the PSD as well as smaller average size of grains can be explained by the stepwise change of the material's surface charge from highly negative to highly positive, which impacts on a separation of agglomerated particles of SBA-15.

The changes in the size of SBA-15 particles and their homogeneity after PVAm grafting were additionally confirmed by the SEM observations. In the Fig. 6, the SEM images for pristine SBA-15 (Fig. 6a) and the SBA-15_ GPTMS_PVAm_2.50 (Fig. 6b) samples are presented.

The silica surface functionalization resulted in a disengagement of the material and a decrease in the average particle size, wherein the grains shape was more congenial than in the unmodified SBA-15.

The mechanism of attachment of PVAm to the SBA-15 surface during the "grafting onto" process was monitored by DRIFT spectroscopy. The DRIFT spectra of calcined SBA-15, epoxy-functionalized SBA-15 (SBA-15_ GPTMS_2.00) and polyvinylamine-based hybrid material (SBA-15_GPTMS_PVAm_2.00) are shown in Fig. 7. In the spectrum of pristine SBA-15, a narrow and intensive peak at $3745 \mathrm{~cm}^{-1}$, due to the stretching mode of free silanol groups (Si-OH), and a broad band in the range of $3100-3500 \mathrm{~cm}^{-1}$, due to the hydrogen bonding of silanols, are observed [32]. After the functionalization with epoxy-silane, the intensity of these characteristic bands is attenuated. It is caused by reactions involving the surface $\mathrm{Si}-\mathrm{OH}$ groups and methoxy groups of organosilanes. Furthermore, the appearance of new bands characteristic of GPTMS in the spectrum of epoxy-functionalized silica confirms the successful modification of the silica support. Very weak peaks at 905, 2990 and $3055 \mathrm{~cm}^{-1}$ are b)

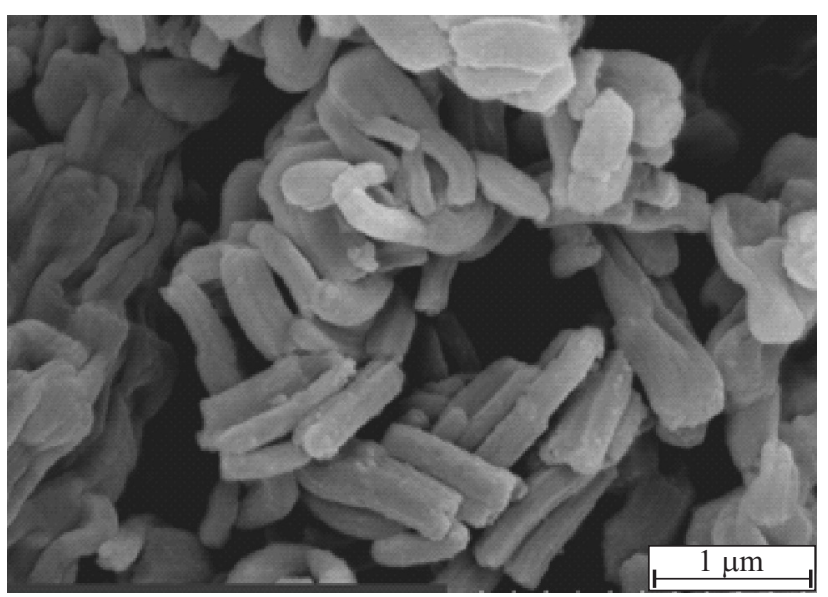

Fig. 6. SEM images collected for: a) pristine SBA-15, b) SBA-15_GPTMS_PVAm_2.50 


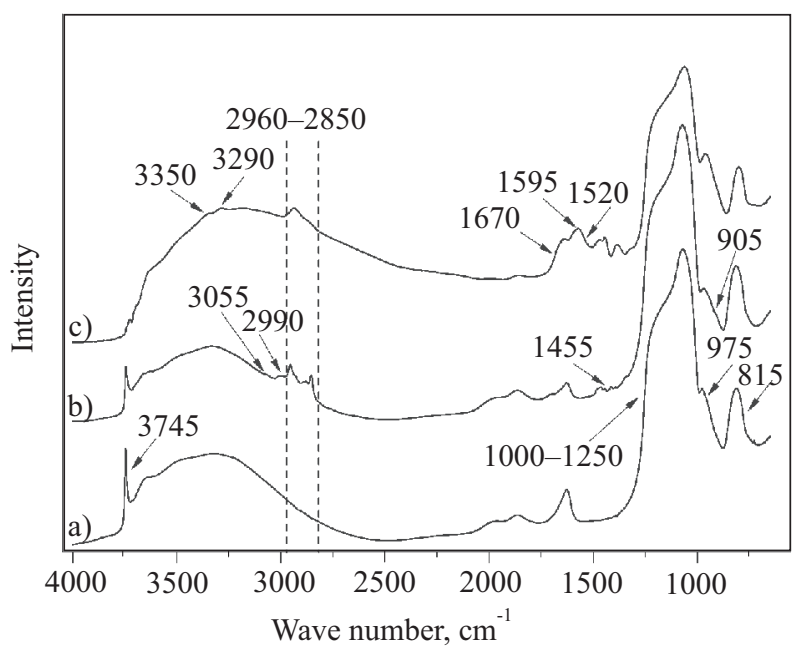

Fig. 7. DRIFT spectra collected for: a) pristine SBA-15, b) SBA-15_GPTMS_2.00, c) SBA-15_GPTMS_PVAm_2.00

assigned to the stretching vibrations and ring deformations of epoxy group, whereas a band at $1445 \mathrm{~cm}^{-1}$ corresponds to the $\mathrm{CH}_{2}$ scissoring of glycidoxy groups [33]. The presence of signals due to the stretching mode of methoxy groups (in the region of $2850-2960 \mathrm{~cm}^{-1}$ ) suggests that GPTMS is grafted on the silica surface by less than three R-Si-O-(silica) links. The representative spectrum of PVAm/SBA-15 hybrid material prepared by grafting "onto" shows new absorption bands in the ranges of $1300-1700$ and $2800-3400 \mathrm{~cm}^{-1}$ [34, 35]. In the high frequency region, peaks at 3290 and $3350 \mathrm{~cm}^{-1}$ indicate the presence of asymmetric and symmetric N-H stretching modes of primary amino groups. An additional peak at $1595 \mathrm{~cm}^{-1}$ may be assigned to the N-H out-of-plane bending vibration of - $\mathrm{NH}_{2}$ groups. Moreover, bands at 1520 and $1670 \mathrm{~cm}^{-1}$ appear due to the deforming vibrations of protonated amino species and the stretching vibrations of $\mathrm{C}=\mathrm{O}$ in residual formamido groups, respectively. Lastly, the stretching $\left(2850-2960 \mathrm{~cm}^{-1}\right)$ and deforming (1350-1460 $\left.\mathrm{cm}^{-1}\right)$ vibrations of C-H in the polymer backbone are clearly noticeable.

The chemical structure of the polymer-silica hybrid materials was studied by XPS. To obtain the detailed information on chemical bonding, the deconvolution of high-resolution spectra was performed. The atomic contributions of particular surface species are summarized in Table 3.

As displayed in Fig. 8, the $\mathrm{C}$ 1s spectra can be resolved into four components. Two main components are related to aliphatic carbons (C-C and/or C-H bonds) in the polymer chains $(285.3 \pm 0.1 \mathrm{eV})$ and carbon atoms in the $\mathrm{C}-\mathrm{N}$ and C-O groups $(286.4 \pm 0.1 \mathrm{eV})[36,37]$. It is noteworthy that the intensity of these characteristic peaks increases with the polymer loading that readily suggests the appearance of PVAm grafted on the silica surface. For the samples with low PVAm/ $\mathrm{SiO}_{2}$ mass ratios (SBA-15_ GPTMS_PVAm_0.10-0.75), the component from the unreacted oxirane rings is still observed $(287.3 \mathrm{eV})$. It can be explained by the very slow saturation of surface by the a)

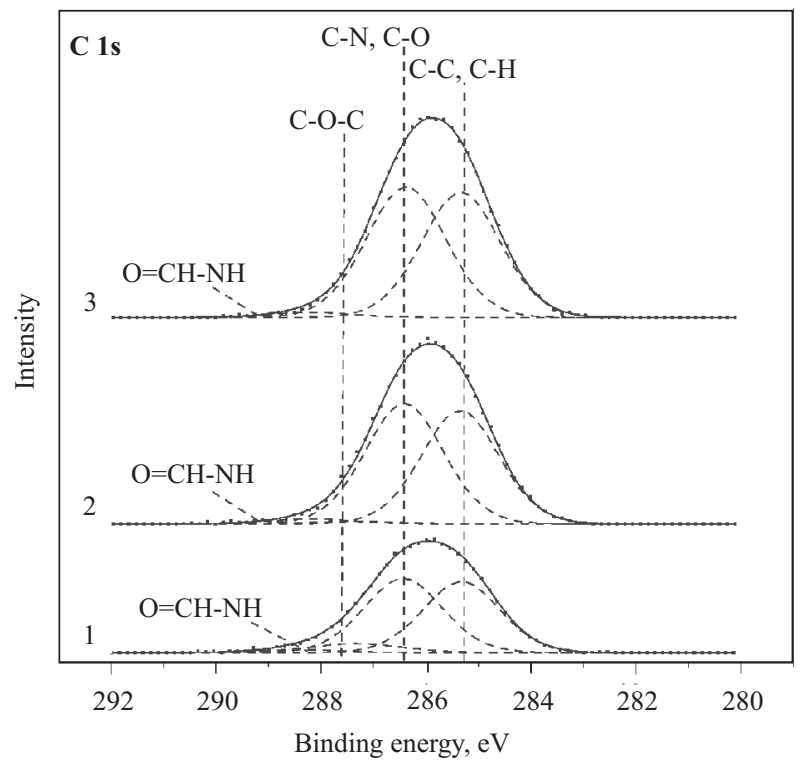

b)

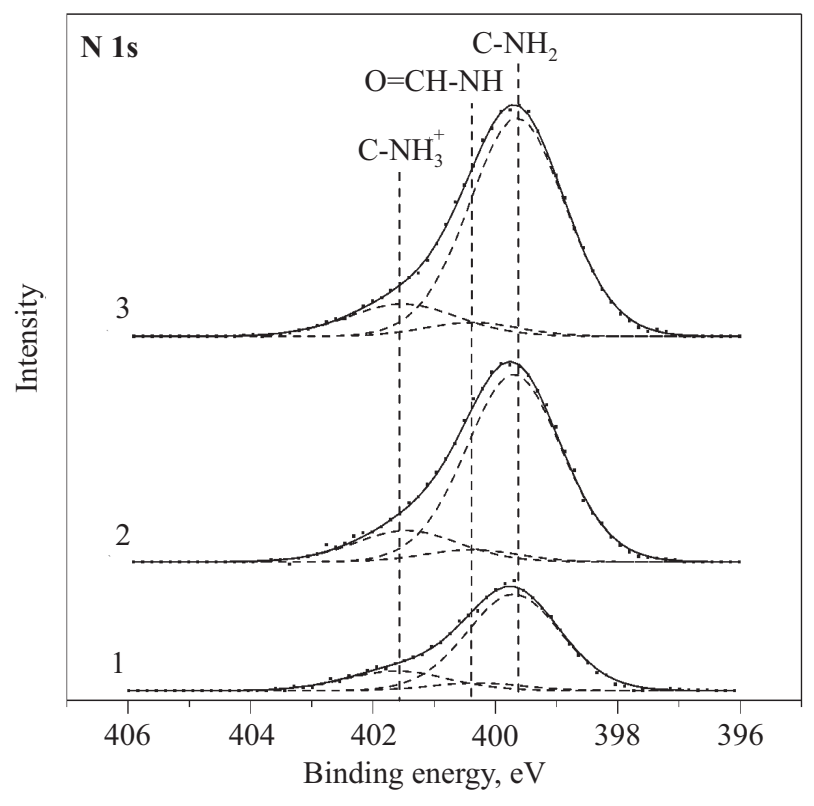

Fig. 8. The high-resolution: a) C 1s, b) $\mathrm{N}$ 1s spectra for selected polyvinylamine-functionalized samples: 1 - SBA-15_GPTMS PVAm_0.10, 2 - SBA-15_GPTMS_PVAm_0.75, 3 - SBA-15 GPTMS_PVAm_2.00

PVAm chains, even in the high excess of the polymer applied. The last $C$ 1s peak at $288.3 \pm 0.1 \mathrm{eV}$ originates from the carbon atoms in the unhydrolyzed formamide groups $(\mathrm{O}=\mathrm{CH}-\mathrm{NH})$. The grafted PVAm can be easily identified by the presence of $\mathrm{N} 1$ s peak that results from $\mathrm{N}$-containing species in this polymer as well (see Fig. 8). For all PVAm-functionalized samples, in the $\mathrm{N} 1 \mathrm{~s}$ high-resolution spectra, we distinguish three different components related to: (i) non-protonated, primary amino groups $(399.6 \pm 0.1 \mathrm{eV})$, (ii) formamide groups $(400.3 \pm 0.1 \mathrm{eV})$, 
$\mathrm{T}$ a b 1 e 3. Atomic contributions of surface species detected in SBA-15 silica modified with different amounts of polyvinylamine (binding energies given in parentheses)

\begin{tabular}{|c|c|c|c|c|c|c|c|c|}
\hline \multirow{3}{*}{ Sample } & \multicolumn{8}{|c|}{ Surface composition (at \%) } \\
\hline & \multicolumn{4}{|c|}{$\mathrm{C} 1 \mathrm{~s}$} & \multirow[b]{2}{*}{$\mathrm{N} 1 \mathrm{~s}$} & \multirow[b]{2}{*}{$\mathrm{O} 1 \mathrm{~s}$} & \multirow[b]{2}{*}{ Si $2 p$} & \multirow[b]{2}{*}{$\mathrm{Cl} 2 \mathrm{p}$} \\
\hline & $\begin{array}{c}\text { C-C, }, \underline{C}-\mathrm{H} \\
(285.3 \pm 0.1 \mathrm{eV})\end{array}$ & \begin{tabular}{|c|} 
C-O,,$\underline{\mathrm{C}}-\mathrm{N}$ \\
$(286.4 \pm 0.1 \mathrm{eV})$
\end{tabular} & $\begin{array}{c}\text { C-O-C } \\
(287.3 \mathrm{eV})\end{array}$ & $\begin{array}{c}\mathrm{O}=\underline{\mathrm{C}}-\mathrm{NH} \\
(288.3 \pm 0.1 \mathrm{eV})\end{array}$ & & & & \\
\hline SBA-15 & - & - & - & - & - & 65.20 & 34.80 & - \\
\hline SBA-15_GPTMS_2.00 & 1.98 & 2.78 & 1.85 & - & - & 61.40 & 31.99 & - \\
\hline SBA-15_GPTMS_PVAm_0.10 & 7.31 & 7.76 & 1.11 & 0.33 & 5.35 & 50.48 & 27.37 & 0.28 \\
\hline SBA-15_GPTMS_PVAm_0.25 & 8.91 & 9.71 & 0.77 & 0.37 & 7.56 & 47.00 & 25.29 & 0.37 \\
\hline SBA-15_GPTMS_PVAm_0.50 & 9.48 & 10.25 & 0.69 & 0.41 & 8.20 & 45.95 & 24.63 & 0.39 \\
\hline SBA-15_GPTMS_PVAm_0.75 & 10.07 & 10.81 & 0.25 & 0.45 & 8.71 & 45.04 & 24.27 & 0.41 \\
\hline SBA-15_GPTMS_PVAm_1.00 & 10.32 & 11.04 & - & 0.47 & 8.98 & 44.73 & 24.15 & 0.31 \\
\hline SBA-15_GPTMS_PVAm_1.50 & 10.90 & 11.65 & - & 0.49 & 9.78 & 43.23 & 23.51 & 0.44 \\
\hline SBA-15_GPTMS_PVAm_2.00 & 11.35 & 11.96 & - & 0.51 & 10.10 & 42.54 & 23.09 & 0.45 \\
\hline SBA-15_GPTMS_PVAm_2.50 & 11.70 & 12.27 & - & 0.54 & 10.44 & 42.00 & 22.65 & 0.41 \\
\hline
\end{tabular}

and (iii) hydrogen bonded or protonated amino species $(401.5 \pm 0.1 \mathrm{eV})$ [36-38]. The contribution of primary amino groups estimated on the basis of the XPS results changes from 76.6\% (for SBA-15_GPTMS_PVAm_0.10) to $81.3 \%$ (for SBA-15_GPTMS_PVAm_2.50). It should therefore be concluded that the attachment of PVAm to the surface of epoxy-functionalized SBA-15 through the ring-opening reaction results in the formation of polymer-silica hybrid materials with a very high amount of accessible and highly reactive primary amino groups. Moreover, in the wide-scan spectra of polymer-silica hybrid materials (not shown here), apart from the expected $\mathrm{Si}$ and $\mathrm{O}$ atoms, $\mathrm{Cl} 2 \mathrm{p}$ and $\mathrm{Cl} 2 \mathrm{~s}$ peaks are observed. The binding energy of the $\mathrm{Cl} 2 \mathrm{p}$ peak $(198.0 \pm 0.1 \mathrm{eV})$ suggests traces of chloride anions incorporated during the PVAm grafting.

\section{CONCLUSIONS}

It was proved that silanols present on a surface of SBA-15 type mesoporous $\mathrm{SiO}_{2}$ easily react with 3-glycidoxypropyltrimethoxysilane forming a material suitable to grafting of polyvinylamine chains. This modification is based on opening of oxirane rings engaging $\mathrm{NH}_{2}$ functionalities of PVAm. Thus, homogeneously distributed polymer chains with free amine groups can be deposited on the silica surface by this way. Such materials can be used in many different applications demanding basic solids, for example as catalysts in various condensation processes.

\section{ACKNOWLEDGMENTS}

This work was supported by the National Science Centre under the grant no. 2012/07/B/ST5/00917. Anna Wach wishes to thank Lesser Poland Scholarship Fund for PhD students "Doctus" co-financed by European Social Fund for the financial support. The research was carried out with the equipment purchased thanks to the financial support of the European Regional Development Fund in the framework of the Polish Innovation Economy Operational Program (contract No. POIG.02.01.00-12-023/08).

\section{REFERENCES}

[1] Beck J.S., Vartuli J.C., Roth W.J. et al.: Journal of the American Chemical Society 1992, 114, 10834. http://dx.doi.org/10.1021/ja00053a020

[2] Soler-Illia G.J. de A.A., Sanchez C., Lebeau B., Patarin J.: Chemical Reviews 2002, 102, 4093. http://dx.doi.org/10.1021/cr0200062

[3] Deng Y., Wei J., Sun Z. et al.: Chemical Society Reviews 2013, 42, 4054.

http://dx.doi.org/10.1039/C2CS35426H

[4] Trong-On D., Desplantier-Giscard D., Danumah C., Kaliaguine S.: Applied Catalysis A: General 2003, 253, 545. http://dx.doi.org/10.1016/S0926-860X(03)00194-7

[5] Zhao L., Qin H., Wu R. et al.: Journal of Chromatography A 2012, 1228, 193. http://dx.doi.org/10.1016/j.chroma.2011.09.051

[6] Tang F., Li L., Chen D.: Advanced Materials 2012, 24, 1504. http://dx.doi.org/10.1002/adma.201104763

[7] Bescher E., Mackenzie J.D.: Materials Science and Engineering: C 1998, 6, 145. http://dx.doi.org/10.1016/S0928-4931(98)00039-3

[8] Hoffmann F., Cornelius M., Morell J. et al.: Angewandte Chemie International Edition 2006, 45, 3216. http://dx.doi.org/10.1002/anie.200503075

[9] Park S.S., Ha C.-S.: The Chemical Record 2006, 6, 32. http://dx.doi.org/10.1002/tcr.20070

[10] Jose T., Sudheesh N., Shukla R.S.: Journal of Molecular Catalysis A: Chemical 2010, 333, 158. http://dx.doi.org/10.1016/j.molcata.2010.10.012

[11] Yokoi T., Kubota Y., Tatsumi T.: Applied Catalysis A: General 2012, 421-422, 14. http://dx.doi.org/10.1016/j.apcata.2012.02.004

[12] Blasco-Jiménez D., Sobczak I., Ziolek M. et al.: Catalysis Today 2010, 152, 119. http://dx.doi.org/10.1016/j.cattod.2010.04.031

[13] Wach A., Drozdek M., Dudek B. et al.: The Journal of Physical Chemistry C 2015, 119, 19954. 
http://dx.doi.org/10.1021/acs.jpcc.5b05868

[14] Wach A., Drozdek M., Dudek B. et al.: Surface and Interface Analysis 2014, 46, 1021.

http://dx.doi.org/10.1002/sia.5468

[15] Alekseev S.A., Zaitsev V.N., Fraissard J.: Chemistry of Materials 2006, 18, 1981. http://dx.doi.org/10.1021/cm052776a

[16] Yamazaki R., Karyu N., Noda M. et al.: Journal of Applied Polymer Science 2015, 133, 43256. http://dx.doi.org/10.1002/app.43256

[17] Zhang L., He Y., Feng S. et al.: Ceramics International 2016, 42, 6178. http://dx.doi.org/10.1016/j.ceramint.2015.12.178

[18] Barbey R., Klok H.-A.: Langmuir 2010, 26, 18219. http://dx.doi.org/10.1021/la102400z

[19] Minko S., Patil S., Datsyuk V. et al.: Langmuir 2002, 18, 289. http://dx.doi.org/10.1021/la015637q

[20] Tissot H., Gallet J.-J., Bournel F. et al.: The Journal of Physical Chemistry C 2014, 118, 24397. http://dx.doi.org/10.1021/jp407411k

[21] Jakša G., Štefane B., Kovač J.: Surface and Interface Analysis 2013, 45, 1709. http://dx.doi.org/10.1002/sia.5311

[22] Penn L.S., Hunter T.F., Quirk R.P. et al.: Macromolecules 2002, 35, 2859. http://dx.doi.org/10.1021/ma011114d

[23] Guillet-Nicolas R., Marcoux L., Kleitz F.: New Journal of Chemistry 2010, 34, 355. http://dx.doi.org/10.1039/B9NJ00478E

[24] Thaiboonrod S., Cellesi F., Ulijn R.V. et al.: Langmuir 2012, 28, 5227. http://dx.doi.org/10.1021/la204606v

[25] Choi M., Kleitz F., Liu D. et al.: Journal of the American Chemical Society 2005, 127, 1924. http://dx.doi.org/10.1021/ja044907z

[26] Zhang F., Yan Y., Yang H. et al.: The Journal of Physical Chemistry B 2005, 109, 8723. http://dx.doi.org/10.1021/jp044632+
[27] Pollock R.A., Gor G.Y., Walsh B.R. et al.: The Journal of Physical Chemistry C 2012, 116, 22802. http://dx.doi.org/10.1021/jp303150e

[28] Reichhardt N.V., Guillet-Nicolas R., Thommes M. et al.: Physical Chemistry Chemical Physics 2012, 14, 5651. http://dx.doi.org/10.1039/C2CP22523A

[29] Gao Q., Xu W., Xu Y. et al.: The Journal of Physical Chemistry B 2008, 112, 2261. http://dx.doi.org/10.1021/jp0763580

[30] Tao Q., Xu Z., Wang J. et al.: Microporous and Mesoporous Materials 2010, 131, 177. http://dx.doi.org/10.1016/j.micromeso.2009.12.018

[31] Tang Y., Zong E., Wan H. et al.: Microporous and Mesoporous Materials 2012, 155, 192. http://dx.doi.org/10.1016/j.micromeso.2012.01.020

[32] Vilarrasa-García E., Cecilia J.A., Santos S.M.L. et al.: Microporous and Mesoporous Materials 2014, 187, 125. http://dx.doi.org/10.1016/j.micromeso.2013.12.023

[33] Šapić I.M., Bistričić L., Volovšek V. et al.: Spectrochimica Acta Part A: Molecular and Biomolecular Spectroscopy 2009, 72, 833.

http://dx.doi.org/10.1016/j.saa.2008.11.032

[34] Neuhaus S., Padeste C., Solak H.H., Spencer N.D.: Polymer 2010, 51, 4037. http://dx.doi.org/10.1016/j.polymer.2010.07.002

[35] Thaiboonrod S., Berkland C., Milani A.H. et al.: Soft Matter 2013, 9, 3920. http://dx.doi.org/10.1039/C3SM27728C

[36] Seifert S., Höhne S., Simon F. et al.: Langmuir 2012, 28, 14935. http://dx.doi.org/10.1021/la302855f

[37] Noel S., Liberelle B., Robitaille L., De Crescenzo G.: Bioconjugate Chemistry 2011, 22, 1690. http://dx.doi.org/10.1021/bc200259c

[38] Graf N., Yegen E., Gross T. et al.: Surface Science 2009, 603, 2849. http://dx.doi.org/10.1016/j.susc.2009.07.029

Received 9 II 2017. 